\title{
Comparative Chemical Study of MTA and Portland Cements
}

\author{
Marília Gerhardt de OLIVEIRA ${ }^{1}$ \\ Cristina Braga XAVIER ${ }^{2}$ \\ Flávio Fernando DEMARCO ${ }^{3}$ \\ Antônio Luis Barbosa PINHEIRO ${ }^{4}$ \\ Aline Tempel COSTA ${ }^{1}$ \\ Daniel Humberto POZZA ${ }^{4}$
}

\author{
${ }^{1}$ Department of Surgery, Pontifical Catholic University of Rio Grande do Sul, Porto Alegre, RS, Brazil \\ ${ }^{2}$ Department of Surgery and Traumatology and Oral and Maxillofacial Prosthodontics, \\ School of Dentistry, Federal University of Pelotas, Pelotas, RS, Brazil \\ ${ }^{3}$ Department of Restorative Dentistry, School of Dentistry, Federal University of Pelotas, Pelotas, RS, Brazil \\ ${ }^{4}$ Laser Center, School of Dentistry, Federal University of Bahia, Salvador, BA, Brazil
}

Portland cement has been analyzed and compared to mineral trioxide aggregate (MTA) because of their chemical similarity. The possibility of using this material as a less expensive alternative to MTA in dental practice should be considered. In view of this, the present study compared the components of a Portland cement $\left(\right.$ Votoran $\left.^{\circledR}\right)$ to two commercial brands of MTA (Pro-Root ${ }^{\mathrm{TM}}$ and MTAAngelus ${ }^{\circledR}$ ). Twelve specimens of each material were fabricated and examined by scanning electron microscopy (SEM) with energy dispersive spectroscopy (EDS) to obtain their percentage of chemical elements. The means of the chemical elements found in each material was compared by descriptive statistics. Bismuth was present only in MTA cements to provide radiopacity. In conclusion, the tested cements have similar components, which supports, as far as composition is concerned, the possible clinical use of Portland as an option to MTA.

Key Words: MTA, Portland cement, spectroscopy, scanning electron microscopy.

\section{INTRODUCTION}

Over the time, there has been a continuous search for dental materials that present an ideal combination of good mechanical, physicochemical and biological properties. Concerning the treatment of periapical injuries, this search has been even more incessant.

Cost has currently a great influence on material's. Mineral trioxide aggregate (MTA) has been shown to have good chemical and biological properties (1-7) and its behavior has been extensively investigated in several clinical applications $(8,9)$. The elevated cost of this product, however, has not allowed its use in all levels of health attention. Despite this, if the clinical studies confirm the preliminary favorable laboratory results,
MTA will probably be the retrofilling material of choice in most situations (1).

Several studies have found better results with the use of MTA when compared to other retrofilling materials, such as glass ionomer cements, zinc oxide and eugenol (IRM), reinforced zinc oxide and eugenol (Super-EBA), amalgam and composite resin. The main characteristics that are responsible for the superiority of MTA include biocompatibility, lesser apical infiltration in parendodontic surgeries (2-4), lesser bacterial microleakage (5) and improved marginal adaptation to the cavity walls $(6,7)$.

Different studies have compared the components of MTA and Portland cement, a material used in civil engineering, due to their chemical and physical similar- 
ity $(5,8)$. Both materials are composed of calcium phosphate, calcium oxide and silica. MTA, however, contains bismuth oxide, an element that provides radiopacity (6).

The possibility of using Portland cement as a less expensive alternative to MTA in dental practice should be considered. In view of this, the present study was designed to perform an in vitro comparative analysis of the components of a Portland cement (Votoran ${ }^{\circledR}$; São Paulo, SP, Brazil) and two commercial brands of MTA (ProRoot ${ }^{\mathrm{TM}}$ MTA; Dentsply/Tulsa Dental, Tulsa, OK, USA) and MTA-Angelus ${ }^{\circledR}$ (Angelus Indústria de Produtos Odontológicos Ltda., Londrina, PR, Brazil).

\section{MATERIAL AND METHODS}

For scanning electron microscopic analysis with energy dispersive spectroscopy (EDS), 12 disc-shaped specimens (5 mm diameter X $1 \mathrm{~mm}$ height) of each material were fabricated according to the manufacturers' instructions, totalizing 36 specimens. The experiment was conducted at the Microanalysis and Microscopy Laboratory of the Pontifical Catholic University of Rio Grande do Sul, Porto Alegre, RS, Brazil. The specimens were fixed to labeled metallic stubs (Aluminum SEM Specimen Mount Stub; Cat. 75200; Electron Microscopy Sciences, Fort Washington, PA, USA) using doublefaced adhesive carbon tape (Nisshin Engineering Co. Ltd., Tokyo, Japan) and placed in a glass desiccator containing silica gel for 2 weeks to allow complete removal of humidity. Thereafter, the specimens were sputter-coated with gold (60 mA; Sputter Coater SCD 005; Baltec AG, Balzers, Liechtenstein), placed into the SEM vacuum camera and submitted to a pressure of approximately 10-5 torr. In this process, the tungsten filament is heated to release the electron bundle, which occurs on the specimen to scan its surface. Images are formed from electrical signals or $x$-rays released by the specimen. These images result from the interaction between the incident bundle and the specimen.

EDS was used to analyze the chemical elements present on the specimens, as it allows determining the intensity of the x-ray counting for a certain element. EDS data were randomly collected in three different sites of each specimen in graphs and subsequently transformed in numerical values. The gold used for sputter coating the specimens was excluded from the percentage of metals found.

The means of the chemical elements found in each material were compared by descriptive statistics.

\section{RESULTS AND DISCUSSION}

The collected EDS data are given in Table 1.

Similar chemical elements were found in all materials and there was a small percentile variation among them. Bismuth was detected only in MTA composition. In spite of the chemical similarity, it was observed a difference in the texture and in the particles of each material (Figures 1 to 3).

MTA is composed by tricalcium silicate, tricalcium oxide, silicate oxide and other mineral oxides that are responsible for its physical and chemical properties. Powder hydration results in a colloidal gel that solidifies in less than $4 \mathrm{~h}$ and has compressive strength similar to that of amalgam. The advantages of MTA include the fact that the presence of a dry area is not essential and its ease of handling, application and removal. A disadvantage of MTA is its long setting time (9).

The $\mathrm{pH}$ and calcium ion release from the two commercial brands of MTA evaluated in the present study (Pro-root ${ }^{\mathrm{TM}}$-MTA and MTA-Angelus ${ }^{\circledR}$ ) have been investigated by Duarte et al. (10). To stimulate tissue mineralization, these materials are supposed to have an alkaline $\mathrm{pH}$ and calcium release. The specimens were immersed in deionized water and the water $\mathrm{pH}$ and the release of calcium ions were measured 3, 24, 72 and 168 $\mathrm{h}$ after immersion. The authors observed that the $\mathrm{pH}$

Table 1. Percent distribution of the elements in the tested materials.

\begin{tabular}{|c|c|c|c|c|c|c|c|c|}
\hline Cement & $\mathrm{C}$ & $\mathrm{O}$ & Mg & $\mathrm{Si}$ & $\mathrm{Ca}$ & $\mathrm{Fe}$ & $\mathrm{Al}$ & $\mathrm{Bi}$ \\
\hline Portland & $10.89 \%$ & $30.42 \%$ & $1.41 \%$ & $10.70 \%$ & $37.93 \%$ & $1.51 \%$ & $4.66 \%$ & - \\
\hline ProRoot ${ }^{\mathrm{TM}}$-MTA & $10.97 \%$ & $34.39 \%$ & $0.92 \%$ & $6.06 \%$ & $36.04 \%$ & $2.39 \%$ & - & $9.20 \%$ \\
\hline Angelus ${ }^{\circledR}$-MTA & $9.44 \%$ & $29.61 \%$ & $0.94 \%$ & $3.40 \%$ & $44.37 \%$ & - & $0.86 \%$ & $9.09 \%$ \\
\hline
\end{tabular}


was higher and the released of calcium ions was more accentuated within the first $3 \mathrm{~h}$. Regarding MTAAngelus $^{\circledR}$, these values were slightly higher at all time intervals, probably because of its greater amount of Portland cement or other calcium release agents.

According to its manufacturer, MTA-Angelus ${ }^{\circledR}$ does not require an awaiting time for hardening because its properties are improved in contact with a humid environment. MTA cements hve a $\mathrm{pH}$ of 10.2 soon after mixture, which is increased to 12.5 after $3 \mathrm{~h}$ and remains stable. The gel solidifies after $4 \mathrm{~h}$ and reaches its highest resistance to compression (70 Mpa) after 21 days (9). When placed in an environment with acid pH, MTA has its apical sealing capacity increased (11).

Economides et al. (12) evaluated the short-term response from dogs' periradicular tissues to MTA used as a retrofilling material in absence of pathologies.

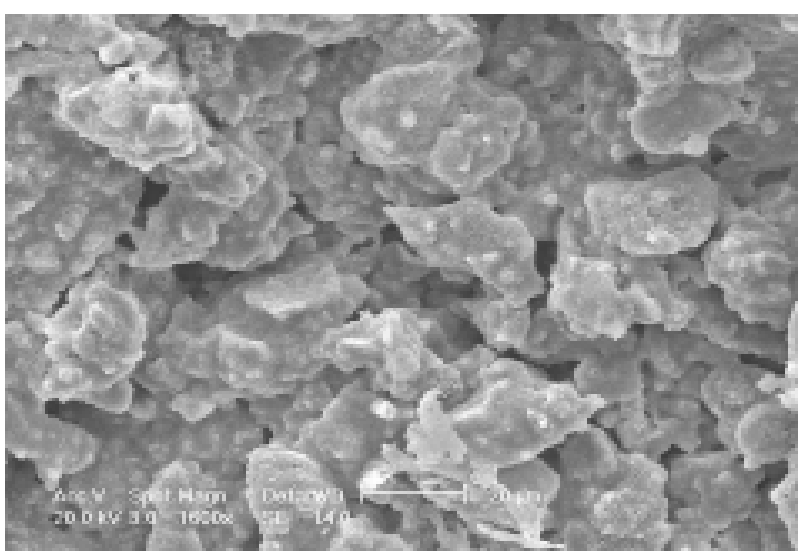

Figure 1. SEM micrograph of a Portland cement specimen.

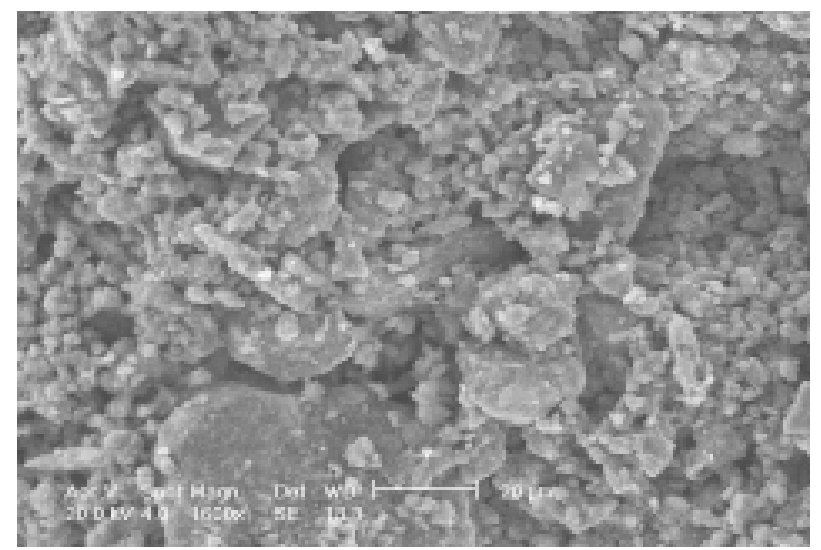

Figure 2. SEM micrograph of a MTA Pro-Root ${ }^{\mathrm{TM}}$ specimen.
Tissue response was assessed between 1 and 5 weeks. The main observed characteristic was the presence of connective tissue after the first week. The presence of hard tissue around all MTA-filled specimens was also observed. The authors concluded that MTA is a biocompatible material that stimulates the repair of the periradicular tissues. MTA is generally mentioned as a dental material of great value for cases of non-favorable prognosis for parendodontic surgery and reportedly increases the success rates of any other procedures in which it is used $(8,9)$. However, its cost is still high. Due to its chemical similarity to MTA, Portland cement has been investigated as a possible alternative material.

A previous study (13) investigated the chemical and antibacterial properties of various materials including Portland cement and MTA and found that that both cements are constituted of the same elements, except for bismuth (13).

In a comparative analysis of mineral trioxide aggregate and Portland cement using plasma emission spectrometry (ICP-ES), Funteas et al. (14) evaluate 15 elements of MTA and Portland cement composition. The results showed similarities between the materials, except for the fact that there was no detectable quantity of bismuth in Portland cement. It was concluded that there was no significant difference between the other 14 elements in both Portland cement and MTA.

In the present study, a Portland cement (Votoran ${ }^{\circledR}$ ) was used because the findings of a previous investigation (15) demonstrated the biocompatibility of this cement after implantation of this material in polyethylene tubes in the subcutaneous connective tissue of the

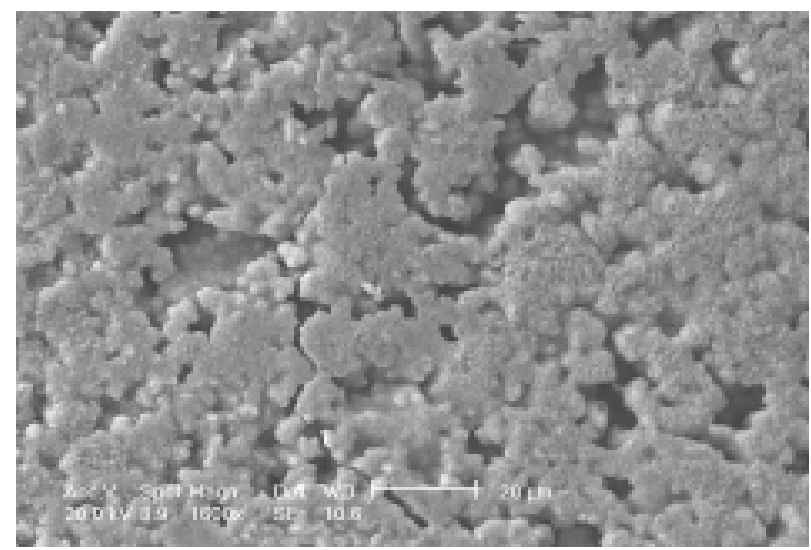

Figure 3. SEM micrograph of an Angelus ${ }^{\circledR}$-MTA specimen. 
rats during 7, 12 and 60 days.

According to its manufacturer's MSDS (material safety data sheet), Pro-Root ${ }^{\mathrm{TM}}$-MTA has in its composition $75 \%$ Portland cement, $20 \%$ bismuth oxide and $5 \%$ dehydrated calcium sulfate. According to its manufacturer, MTA-Angelus ${ }^{\circledR}$ is composed of $80 \%$ Portland cement and 20\% bismuth oxide and no calcium sulfate (gypsum). The absence of calcium sulphate is advertised to reduce the setting time to $10 \mathrm{~min}$.

In this study, MTA-Angelus ${ }^{\circledR}$ presented the highest amount of calcium in its composition (44.37\%). However, this chemical element was not in the form of dehydrated calcium sulphate, as the information provided by the manufacturer.

The constituents of the Portland cement are minerals, among which the most important are tricalcium silicate $\left(3 \mathrm{CaO} . \mathrm{SiO}_{2}\right)$, dicalcium silicate $\left(2 \mathrm{CaO} . \mathrm{SiO}_{2}\right)$, tricalcium aluminate $\left(3 \mathrm{CaO} \cdot \mathrm{Al}_{2} \mathrm{O}_{3}\right)$, tetracalcium ironaluminate $\left(4 \mathrm{CaO} \cdot \mathrm{Al}_{2} \mathrm{O}_{3} \cdot \mathrm{Fe}_{2} \mathrm{O}_{3}\right)$ and dehydrated calcium sulfate $\left(\mathrm{CaO} \cdot \mathrm{SO}_{3} \cdot 2 \mathrm{H}_{2} \mathrm{O}\right)(16)$. The findings of the present study are in accordance with these results despite the different methods of comparison used.

Bismuth oxide, which is insoluble, is added to MTA to provide radiopacity (14). In the present study, Pro-Root ${ }^{\mathrm{TM}}$-MTA presented the highest percentages of bismuth (9.2\% on the average). Except for bismuth, Portland cement and MTA cements presented similar chemical formulations.

De Deus et al. (17) evaluated the cytotoxic effects of two brands of MTA (Angelus ${ }^{\circledR}$-MTA and Pro-Root ${ }^{\mathrm{TM}}$-MTA) and Portland cement on human ECV 304 endothelial cell line. All cements initially showed a similar elevated cytotoxic effect that decreased gradually with time allowing the cell culture to become reestablished. It has been reported that, based on the good results obtained in the pulpal treatment with Portland cement and MTA, bismuth oxide does not influence negatively the biological properties of MTA (18). Other studies have demonstrated that good properties of MTA are also present in the Portland cement. Estrela et al. (19) found that the inhibition zones to $S$. aureus, E, faecalis and B. subtilis were identical for both materials. This indicates that, despite the slight difference in their compositions, these cements have similar properties, are atoxic and allow cellular adhesion, which means that bone formation is likely to be stimulated. The outcomes of the present study showed that bismuth was present only in both MTA cements.
This chemical element, used as radiopacifier, is not responsible for the biocompatibility of the MTA, and so bismuth is not a necessary element for civil engineering cement such as the Portland cement.

In conclusion, the tested cements have similar components, which supports that, as far as composition is concerned, the possible clinical use of Portland as an option to MTA.

\section{RESUMO}

O cimento Portland tem sido analisado e comparado com o agregado trióxido mineral (MTA) devido a sua similaridade química. Dada à possibilidade de uso na Odontologia como uma alternativa menos onerosa ao MTA, realizou-se uma análise comparativa dos componentes do cimento Portland (Votoran ${ }^{\circledR}$ ) com os constituintes de dois cimentos MTA (Pro-Root ${ }^{\mathrm{TM}}$-MTA e Angelus ${ }^{\circledR}$-MTA). Para tanto, foram confeccionados 12 corposde-prova de cada um dos materiais $(n=36)$, e estes foram analisados em microscopia eletrônica de varredura (MEV) pela técnica de espectroscopia por dispersão de energia (EDS), que fornece o percentual dos componentes químicos encontrados nos corpos-de-prova. As médias dos elementos químicos encontrados nos três cimentos foram comparadas por meio de análise estatística descritiva. O bismuto estava presente somente nos cimentos MTA. Concluiu-se que os cimentos testados apresentaram similaridade em seus constituintes, o que indica, considerando-se a composição, a possibilidade de futura utilização clínica do cimento Portland como alternativa ao MTA.

\section{REFERENCES}

1. Johnson BR. Considerations in the selection of a root-end filling material. Oral Surg Oral Med Oral Pathol Oral Radiol Endod 1999;87:398-404.

2. Aqrawabi J. Sealing ability of amalgam, super EBA cement, and MTA when used as retrograde filling materials. Br Dent J 2000;188:266-268

3. Andelin WE, Browning DF, Hsu G-Hong R, Roland DD, Torabinejad M. Microleakage of resected MTA. J Endod 2002;28:573-574.

4. Pereira CL, Cenci MS, Demarco FF. Sealing ability of MTA, Super-EBA, Vitremer and amalgam as root-end filling materials. Braz Oral Res 2004;18:317-321.

5. Scheerer SQ, Steiman R, Cohen J. A comparative evaluation of three root-end filling materials: an in vitro leakage study using Prevotella nigrescens. J Endod 2001;27:40-42.

6. Peters CI, Peters OA. Occlusal loading of EBA and MTA root-end fillings in a computer-controlled masticator: a scanning electron microscopic study. Int Endod J 2002;35:22-29.

7. Gondim E, Zaia AA, Gomes BPFA, Ferraz CCR, Teixeira FB, Souza-Filho FJ. Investigation of the marginal adaptation of root-end filling materials in root-end cavities prepared with ultrasonic tips. Int Endod J 2003;36:491-499.

8. Camilleri J, Montesin FE, Papaioannou S, McDonald F, Pitt Ford TR. Biocompatibility of two commercial forms of mineral trioxide aggregate. Int Endod J 2004,37:699-704. 
9. Torabinejad M, Chivian N. Clinical applications of mineral trioxide aggregate. J Endod 1999;25:197-205.

10. Duarte MAH, Demarchi ACCO, Yamashita JC, Kuga MC, Fraga SCF. pH and calcium íon release of 2 root-end filling materials. Oral Surg Oral Med Oral Pathol 2003;95:345-347.

11. Roy CO, Jeansonne BG, Gerrets TF. Effect o fan acid environment on leakage of root-end filling materials. J Endod 2001;27:7-8.

12. Economides N, Pantelidou O, Kokkas A, Tziafas D. Shortterm periradicular tissue response to mineral trioxide aggregate (MTA) as root-end filling material. Int Endod J 2003;36:44-48.

13. Estrela C, Bammann LL, Estrela CR, Silva RS, Pécora JD. Antimicrobial and chemical study of MTA, Portland cement, calcium hydroxide paste, Sealapex and Dycal. Braz Dent J 2000;11:19-27.

14. Funteas UR, Wallace JA, Fochtman EW. A comparative analysis of mineral trioxide aggregate and Portland cement. Aust Endod J 2003;29:43-44.

15. Moraes SH. Reaction of rat subcutaneous connective tissue to implant of Portland cement. J Bras Endod 2001;2:326329.

16. Weidmann G, Lewis P, Reid N. Structural materials. Oxford: Butterworth Heinemann, 1994 apud Estrela, C, Bammann LL, Estrela CR, Silva RS, Pécora JD. Antimicrobial and chemical study of MTA, Portland cement, calcium hydroxide paste, Sealapex and Dycal. Braz Dent J 2000;11:19-27.

17. De Deus G, Ximenes R, Gurgel-Filho ED, Plotkowski MC, Coutinho-Filho T. Citotoxicity of MTA and Portland cement on human ECV 304 endothelial cells. Int Endod J 2005;38:604-609.

18. Holland R, Souza V, Murata SS, Nery MJ, Bernabé PFE, Otoboni Filho JA, Dezan Júnior E. Healing process of dog dental pulp after pulpotomy and pulp covering with mineral trioxide aggregate or Portland cement. Braz Dent J 2001;12:109-113.

19. Abdullah D. An evaluation of accelerated Portland cement as a restorative material. Biomaterials 2002;23:4001-4010.

Accepted February 26, 2006 